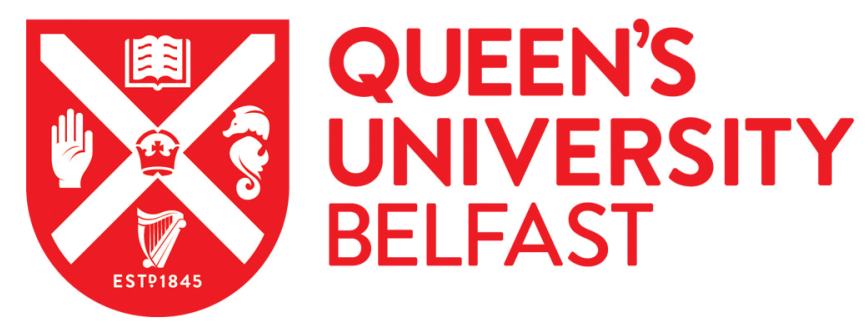

\title{
Alternative routes to piscivory: Contrasting growth trajectories in brown trout (Salmo trutta) ecotypes exhibiting contrasting life history strategies
}

Hughes, M. R., Hooker, O. E., Van Leeuwen, T. E., Kettle-White, A., Thorne, A., Prodöhl, P., \& Adams, C. E. (2018). Alternative routes to piscivory: Contrasting growth trajectories in brown trout (Salmo trutta) ecotypes exhibiting contrasting life history strategies. ECOLOGY OF FRESHWATER FISH.

https://doi.org/10.1111/eff.12421

Published in:

ECOLOGY OF FRESHWATER FISH

Document Version:

Peer reviewed version

Queen's University Belfast - Research Portal:

Link to publication record in Queen's University Belfast Research Portal

\section{Publisher rights}

(C) 2018 John Wiley \& Sons A/S. Published by John Wiley \& Sons Ltd. This work is made available online in accordance with the publisher's policies. Please refer to any applicable terms of use of the publisher.

\section{General rights}

Copyright for the publications made accessible via the Queen's University Belfast Research Portal is retained by the author(s) and / or other copyright owners and it is a condition of accessing these publications that users recognise and abide by the legal requirements associated with these rights.

Take down policy

The Research Portal is Queen's institutional repository that provides access to Queen's research output. Every effort has been made to ensure that content in the Research Portal does not infringe any person's rights, or applicable UK laws. If you discover content in the

Research Portal that you believe breaches copyright or violates any law, please contact openaccess@qub.ac.uk. 
1 Alternative routes to piscivory: Contrasting growth trajectories in brown trout (Salmo trutta) ecotypes exhibiting contrasting life history strategies

Martin R. Hughes ${ }^{1}$ Oliver E. Hooker ${ }^{1}$ Travis E. Van Leeuwen ${ }^{1,2}$ Alan, Kettle-White ${ }^{3}$ Alastair Thorne ${ }^{4}$ Paulo Prodöhl ${ }^{5}$ Colin E. Adams $^{1}$

${ }^{1}$ Scottish Centre for Ecology \& the Natural Environment, IBAHCM, University of Glasgow, Rowardennan, Glasgow, UK

${ }^{2}$ The Cape Eleuthera Institute, Eleuthera, The Bahamas

${ }^{3}$ Argyll Fishery Trust, Cherry Park, Inveraray, Argyll, UK

${ }^{4}$ Marine Scotland Science, Freshwater Laboratory, Pitlochry, UK

${ }^{\mathbf{5}}$ School of Biological Sciences, Queen's University Belfast, Belfast, UK

Running Head: Ferox trout growth trajectories

Acceptance date: 11 May 2018

\section{ABSTRACT}

Large and long lived piscivorous brown trout, Salmo trutta, colloquially known as ferox trout, have been described from a number of oligotrophic lakes in Britain and Ireland. The 'ferox' life history strategy is associated with accelerated growth following an ontogenetic switch to piscivory and extended longevity, (up to 23 years in the UK). Thus ferox trout often reach much larger sizes and older ages than sympatric lacustrine invertebrate feeding trout. Conventional models suggest that $S$. trutta adopting this life history strategy grow slowly before a size threshold is reached, after which, this gape limited predator undergoes a diet switch to a highly nutritional prey source (fish) resulting in a measurable growth acceleration. This conventional model of ferox trout growth was tested by comparing growth trajectories and age structures of ferox trout and sympatric invertebrate feeding trout in multiple lake systems in Scotland. In two of the three lakes examined, fish displaying alternative life history strategies, but living in sympatry, exhibited distinctly different growth trajectories. In the third lake, a similar pattern of growth was observed between trophic groups. Piscivorous trout were significantly older than sympatric invertebrate feeding trout at all sites but ultimate body size was greater in only two of three sites. This study demonstrates that there are multiple ontogenetic growth pathways to achieving piscivory in S. trutta and that the adoption of a piscivorous diet may be a factor contributing to the extension of life span.

Key words: ontogenetic shift; piscivory; diet switch; ferox trout; Salmo trutta; life history 


\section{INTRODUCTION}

The brown trout Salmo trutta L. is a polytypic species that can adopt a multitude of lifehistory strategies (Klemetsen et al., 2003). Lacustrine S. trutta frequently manifest as alternative life history strategies in sympatry, which often differ in one or more of the following: colour (Ferguson \& Mason, 1981), body size (Campbell, 1979), growth rate (Jonsson, Næsje, Jonsson, Saksgård \& Sandlund, 1999), feeding strategy (Grey, 2001) and longevity (Mangel \& Abrahams, 2001). Piscivory is found throughout the native range of $S$. trutta in Europe and western Asia, including some river populations however large, late maturing S. trutta known to live in large deep lakes that feed predominately on Arctic charr Salvelinus alpinus (colloquially referred to as ferox trout), occur in a limited range of lacustrine systems from County Kerry in Ireland to the Ural Mountains in Russia and is found throughout lakes of Northern Britain and Ireland (Greer, 1995; Hughes, Dodd, Maitland \& Adams, 2016a ). Ferox trout are known to grow much larger and live longer than sympatric lacustrine brown trout that feed on macrobenthic and occasionally surface dwelling invertebrates throughout their life (hereafter referred to as invertebrate feeding trout) (Campbell, 1979; Greer, 1995; Mangel, 1996; Mangel \& Abrahams, 2001). Ferox trout are considered a distinct genetic lineage in some locations (Ferguson \& Mason, 1981; Duguid, Ferguson \& Prodöhl, 2006) but may be derived from the same gene-pool in others.

Both environmental and genetic factors have been implicated in the expression and maintenance of the ferox life history (Campbell, 1979; Ferguson \& Mason, 1981; Taggart, Ferguson \& Mason, 1981; Duguid et al., 2006; McKeown, Hynes, Duguid, Ferguson \& Prodöhl, 2010;). While the occurrence of ferox trout is strongly correlated with specific lake environment conditions; large, deep lakes supporting a population of Arctic charr Salvelinus alpinus, are correlated with the occurrence of ferox trout (Campbell, 1979; Greer, 1995; Hughes et al., 2016a). In Lough Melvin (Ireland) and both in Loch Awe and Loch Laggan (Scotland), ferox trout are reproductively isolated and genetically distinct from sympatric invertebrate feeding trout feeding in the littoral or limnetic zones (Ferguson \& Mason, 1981; Ferguson \& Taggart, 1991; Prodöhl, Taggart \& Ferguson, 1992; Duguid et al., 2006). Here ferox trout is defined as a piscivorous $S$. trutta exhibiting morphological adaptation and delayed maturation which may be reproductively isolated from other sympatric S. trutta.

Evidence from the literature (McKeown et al., 2010) suggests that, at least in some locations, when populations of piscivorous trout and invertebrate feeding trout ecotypes occur 
in sympatry, these alternative life histories may not have originated from a single, common, post glaciation invading ancestor. Instead, they may have resulted from multiple colonisation events by different ancestral lineages. For example, ferox trout in Loch Awe and Loch Laggan (Scotland), were found to be genetically more closely related to ferox trout in Lough Melvin (Ireland), than the invertebrate feeding trout ecotype from the same lake (Duguid et al., 2006). Ferox trout are often characterised by a high frequency of the lactate dehydrogenase $100(\mathrm{LDH}$ $C 1 * 100)$ allele, as opposed to the alternative $L D H-C 1 * 90$ allele, which is more frequent in invertebrate feeding brown trout. This only applies to some populations thus high frequencies of LDH-C1*100 have been found in many non-ferox populations (Hamilton et al., 1989; McMeel, Hoey \& Ferguson, 2001). Therefore at least in Lough Melvin, Loch Awe and Loch Laggan, ferox trout belong to a different ancestral lineage from sympatric invertebrate feeding trout (Ferguson \& Taggart, 1991; Duguid et al., 2006).

The alternative views on the taxonomic classification of ferox trout as either a genetically distinct species, or an adopted life history strategy of the S. trutta species complex is still subject to debate, particularly around the genetic support for alternative views. However, a recent review of the taxonomy status of ferox trout by Freyhof \& Kottelat (2008) argues for a reinstatement of the full species status suggested by Ferguson (2004). This view is also supported by McKeown et al. (2010) who carried out a comprehensive phylogeographic study of S. trutta in Britain and Ireland with focus on the origin(s) of the Lough Melvin S. trutta. Full species status is currently conferred on ferox trout by the IUCN, where the species is described as Salmo ferox Jardine, 1835, and categorised as "Data Deficient" on the red list of threatened species.

Using scales to age individual fish and a back-calculation of size-at-age approach, Campbell (1979) investigated the patterns of growth rate in ferox trout. This study proposed that $S$. trutta adopt piscivory after a period of relatively slow growth. However, once a size threshold is attained (Campbell (1979) indicated this being around $30 \mathrm{~cm}$ ) this gape limited predator is able to access fish prey which triggers a period of rapid growth (likely as a direct result of the switch to a highly nutritional prey (Campbell, 1979). In contrast, L'Abée-Lund, Langeland, \& Sægrov (1992) concluded from stomach content analysis of S. trutta ranging from $11 \mathrm{~cm}$ to $50 \mathrm{~cm}$ in length, that a diet switch to piscivory occurred at a much smaller size $(13 \mathrm{~cm})$. This suggests that the size at which piscivory is adopted is variable across populations and prey switching is opportunistic, mostly likely depending on the availability of adequately sized prey; thus a switch to piscivory, may be at least partly, environment dependent and prey 
size dependent (L'Abée-Lund et al., 2002; Kahilainen \& Lehtonen, 2003; Jensen et al., 2012.

The switch in diet exhibited by ferox trout has been linked to increased longevity (Campbell, 1979; Mangel \& Abrahams, 2001), a contrast with a commonly cited concept that caloric restriction extends lifespan (Mangel \& Abrahams, 2001).

The aim of this study was to examine early ontogenetic processes in sympatric invertebrate feeding trout and piscivorous trout, and specifically test if the conventional model of piscivorous trout growth (slow growth followed by a growth acceleration after the adoption of piscivory) is the common pattern across multiple piscivorous trout populations. Thus three hypotheses are tested here:

\section{METHODS}

Three oligotrophic freshwater lakes in Scotland where piscivorous trout are known to occur in sympatry with invertebrate feeding trout ecotypes were sampled. Loch Awe in westcentral Scotland, which drains to the west $\left(56^{\circ} 55^{\prime} \mathrm{N} ; 4^{\circ} 25^{\prime} \mathrm{W}\right)$, Loch Rannoch in central Scotland, which drains to the east $\left(56^{\circ} 40^{\prime} \mathrm{N} ; 4^{\circ} 18^{\prime} \mathrm{W}\right)$ and Loch na Sealga in northern Scotland, which drains westward $\left(57^{\circ} 47^{\prime} \mathrm{N} ; 5^{\circ} 18^{\prime} \mathrm{W}\right)$.

In Loch Awe a number of fish species are present including Arctic charr (S. alpinus) Atlantic salmon (Salmo salar), European eel (Anguilla anguilla), perch (Percafluviatilis), pike (Esox lucius), minnow (Phoxinus phoxinus) three-spined sticklebacks (Gasterosteus aculeatus) and rainbow trout (Oncorhynchus mykiss). In Loch Rannoch there is a similar composition, Arctic charr, Atlantic salmon, European eel, perch, pike, minnow and three-spined sticklebacks. The species composition of Loch Na Sealga is less well known, however Arctic charr and minnow are present (Maitland \& Adams, 2018).

Salmo trutta were sampled over a number of years (1966-2014; $n=72)$ from Loch Awe and Loch Rannoch (1970-2014; n=111) using Nordic gill nets or a non-destructive, specialised rod and line trolling technique used by experienced anglers (Thorne, MacDonald \& Thorley, 2016). All $S$. trutta from Loch na Sealga (2013; $\mathrm{n}=37$ ) were collected using Nordic gill nets, each comprising 12 mesh sizes ranging from 5 to 50mm (Appelberg et al., 1995). The cryptic nature of piscivorous trout and the difficulty of capturing sufficient numbers of specimens is 
well known, thus the sample size used in this study is relatively large compared with previous studies and only possible through multiple year sampling (Duguid et al., 2006).

S. trutta were classified as piscivorous (and thus ferox trout) on the basis of 140 morphological criteria used by Campbell (1979) and Cawdery \& Ferguson (1988). Ferox were 141 defined as $S$. trutta of large body size, expressing large heads and large, obvious teeth relative 142 to the size of the body. Thus, in Loch Awe and Loch Rannoch, S. trutta $>400 \mathrm{~mm}$ fork length 143 (FL), expressing other ferox characteristics were classified as piscivorous trout. Using the same criteria, S. trutta were classified as invertebrate feeding in Loch Awe and Loch Rannoch if $\leq$ $360 \mathrm{~mm}$ FL and without the characteristics defining a piscivorous trout. These classification criteria have been previously validated for the identification of both piscivorous and invertebrate feeding S. trutta using stable isotope analysis in Scottish lakes (Grey, 2001; Hughes, Van Leeuwen, Cunningham \& Adams, 2016b).

S. trutta from Loch na Sealga were killed on collection for a separate population study and were classified as piscivorous or invertebrate feeding based on stomach content analysis. Stomach contents that comprised exclusively fish (Arctic charr S. alpinus and /or minnow $P$. phoxinus) were classified as piscivorous, and those that contained exclusively

154 Chironomid larvae; terrestrial insects) were classified as invertebrate feeders. Stomach contents analysis does not provide any measure of temporal change in diet, only providing a single snapshot in time of recent prey consumption. Samples sizes and length range of piscivorous trout were as follows: Loch Awe N=33, length range: 420mm-1000mm, Loch Rannoch $\mathrm{N}=71$, length range: $400 \mathrm{~mm}-820 \mathrm{~mm}$ and Loch na Selaga $\mathrm{N}=14$, length range: 115mm-330mm and invertebrate feeding trout: Loch Awe $\mathrm{N}=39$, Loch Rannoch $\mathrm{N}=40$ and Loch na Sealga $\mathrm{N}=23$, length range: $135 \mathrm{~mm}-302 \mathrm{~mm}$ (Table I.).

Muscle tissue samples were taken from all trout from Loch na Selaga and stored in ethanol for genetic analysis. Genomic DNA was extracted from tissue samples using the 163 Promega DNeasy 96 kit (Madison, Wisconsin, USA), following the manufacturer's instructions. Each sample comprising a single fish was subsequently screened for the presence of the allele linked to the expression of a ferox life history $\mathrm{LDH}-\mathrm{Cl} * 100$ following protocol described by McMeel et al. (2001).

Scale samples were taken from above the lateral line of each fish from all sites and stored in paper scale packets. Scales were pressed onto acetate using a jeweler's press (DRM 150 press). Imprinted acetates were viewed using a Projectina scale reader. Scales were read 
following guidelines by Shearer (1992) and definitions from Berg \& Grimaldi (1967) and life history terminology used by Allen \& Ritter (1977).

For length-at-age estimates, measurements were made from the scale focus along the longest axis to the edge of the scale $(S t)$, and to the annulus being examined $(S f)$. Thus, the length of the fish at the time a feature was laid down $(L F)$ was estimated by:

$$
L F=L t(S f / S t)
$$

$L t=$ fish fork length at capture;

$S f=$ scale length to annulus $f$;

$S t=$ total scale length $t$.

Von Bertalanffy growth curves were constructed for each population but only for the first six years of growth; the rationale for this being that no invertebrate feeding trout sampled were found older than this age. Population specific Von Bertalanffy growth curves were compared using Likelihood Ratio Tests in R statistical computing and graphics software using the fishmethods package (R Core team, 2016).

\section{RESULTS}

The population-specific modelled Von Bertalanffy growth rate $(\mathrm{K})$ determined over the

197 first six years of growth, differed significantly between piscivorous trout and invertebrate

198 feeding trout ecotypes in Loch Rannoch and Loch Awe $(P<0.001)$ (Table I \& Table II). In contrast, there was no significant difference in growth rate between these alternate life history strategies over this period in Loch na Sealga $(P>0.5)$ (see Table II). The growth pattern of the two life history strategies differed substantively in nature between lakes (Fig 1.). Thus in Loch 
in piscivorous trout in comparison to invertebrate feeding brown trout (Table III). In contrast, in Loch Rannoch, there was no significant difference in growth rate between life history strategies for the first 3 years; however, piscivorous trout showed a higher growth rate from age 4 to age 6. In Loch na Sealga there were no significant differences in growth rate between life history strategies both from age 1 to age 3 nor from age 4 to age 6 (Table III.).

Age structure differed significantly in all three lakes, with piscivorous trout being significantly older in each lake: Awe ((mean age \pm SE) invertebrate feeding trout $3.4 \pm 0.18$ years; piscivorous trout $8.6 \pm 0.36$ years, $P<0.01)$; Rannoch ((mean age $\pm \mathrm{SE})$ invertebrate feeding trout $4.8 \pm 0.14$ years; piscivorous trout $12 \pm 0.29$ years, $P<0.01)$; na Sealga ((mean age $\pm \mathrm{SE}$ ) invertebrate feeding trout $3.8 \pm 0.8$ years; piscivorous trout $4.7 \pm 1.4$ years, $P=$ $<0.01$ ) (Fig 1.).

No significant differences were observed in the frequency of the ferox lineage linked $L D H-C 1 * 100$ allele (exact probability test $P>0.05$ ) between trout representing both life history strategies in Loch na Selaga.

\section{DISCUSSION}

As gape limited predators, $S$. trutta can only handle prey items of a size which is relative to their body size (Steingrímsson \& Gislason, 2002; Jensen, Kahilainen, Amundsen, Gjelland, Tuomaala, Malinen \& Bøhn, 2008). Thus, S. trutta are not able to consume fish prey until they have a body size large enough to allow them to do so. A similar size threshold effect is known to operate in the closely related Arctic charr Salvelinus alpinus (see e.g. Fraser, Adams \& Huntingford, 1998). Since a single fish prey item provides higher levels of energy, growth rates are often thought to be consistently faster among piscivorous trout (Elliot \& Hurley, 2000).

Thus an increase in growth rate following a period of relatively slow growth is the conventional model of a ferox trout growth trajectory (Campbell, 1979), where the switch to a highly nutritional prey source shows a measurable increased growth response following a period of 'typical' (but slower) brown trout growth. S. trutta in Loch Rannoch conform to this model, where trout exhibiting both life history strategies initially grow at approximately the same rate (hypothesis one) but piscivorous express higher growth following a switch to piscivory (hypothesis two) and show an extended longevity (hypothesis three). The difference in mean age between piscivorous and invertebrate feeding brown trout is arguably at least partly a result of the classification of larger (and thus older) fish as being piscivorous for Loch Awe and Loch Rannoch. This effect could not occur however for fish categorized by stomach 
contents from Loch na Sealga. Loch Awe trout also do not conform well to this conventional model of piscivorous growth pattern. A high growth rate of piscivorous trout adopting a piscivorous life history strategy was shown at a very early age (ca between age 1 and age 2 and small size ca 100mm FL - Fig 1 and Table III). There are two possible explanations for the growth pattern observed in Loch Awe. First, piscivorous trout in Loch Awe may switch to piscivory at a very young age (ca $1+$ years) and very small body size $<100 \mathrm{~mm}$. This is very unlikely, as piscivory at this size in S. trutta is uncommon (Campbell, 1979; L'Abée-Lund, Langeland, \& Sægrov, 1992), however this explanation is potentially possible if very small size fish prey are available (Juanes, 1994; Mittelbach \& Persson, 1998). Alternatively, and more plausible, is that trout in Loch Awe, adopting a piscivorous trout life history, comprise the fastest growing individuals before a switch to piscivory. This explanation does not support hypothesis one. The observed high growth rate in young piscivorous trout in Loch Awe suggests that, if this mechanism is in operation, they are highly efficient at acquiring food in a quantity and/or quality as juveniles that exceeds that of trout that adopt an invertebrate feeding life history strategy. This probability is supported by the evidence that progeny of piscivorous trout express higher levels of behavioural dominance compared with the progeny of invertebrate feeders (Hughes et al., 2016b). This possibility implies that there may be a level of inheritance of life history strategy across generations in the Loch Awe ferox population. This is certainly plausible for Loch Awe trout, where genetic analysis has found that the ferox trout population is reproductively isolated from the sympatric invertebrate feeding trout population (Duguid et al., 2006).

Piscivory in Loch na Sealga however, contrasts distinctly with both models. Here, there is no accelerated growth effect of piscivory, and hence hypothesis two is not supported. However, there is consistent evidence that piscivorous trout do live longer in all three lakes, supporting hypothesis three (Fig 1). For Loch Awe and Rannoch there is the possibility that the higher detected average age in piscivorous trout is at least partly the result of selection of individuals of larger size; however, this is not the case of Loch na Selga piscivorous trout which were not markedly larger, but were older than invertebrate feeding trout. Contrary to observations elsewhere (Duguid et al., 2006), there was no evidence in this study for the presence of the $\mathrm{LDH}-\mathrm{Cl} * 100$ allele in piscivorous $\mathrm{S}$. trutta in Loch na Sealga.

In Loch na Sealga, the study presented here demonstrates that $S$. trutta can exploit the ferox trophic niche in the absence of the $\mathrm{LDH}-\mathrm{Cl} 1^{*} 100$ allele. Thus it is most probable that a piscivorous trophic life history strategy may predominate in populations with a high frequency 
of the $L D H-C 1 * 100$ allele but that it can still occur in populations that do not possess the $L D H$ $C 1 * 100$ allele. It also shows that not all $S$. trutta that reach a size threshold that allows a switch to piscivory, do actually make that switch, which is true of all lakes in this study, but most obvious in Loch na Sealga and Loch Rannoch. This may be the result of constraints faced by apex predators, such as that of prey availability (Ford, Ellis, Olesiuk \& Balcomb, 2009). Thus the data presented here support the premise that piscivory can arise as a result of S. trutta being genetically predisposed for that resource specialisation or alternatively as a result of an opportunistic feeding response. It appears that in some cases both of these can occur in the same system. Wollebaek et al., (2018) for example, found genetic differentiation between piscivores and invertebrate feeders only in large tributaries and not in smaller ones of same catchment. These authors suggest that a genetically distinct piscivorous ecotype might be more likely to evolve in the relatively more stable large river habitat. Expressed traits that may enhance efficient foraging on fish, may be expressed through ontogenetic process as a result of phenotypic plasticity. However, if an adaptation to a piscivorous life history is to be inherited, then partial or complete reproductive isolation between emerging piscivorous and sympatric invertebrate ecotypes is needed (Sikkink \& Snellrood, 2016). Piscivorory has been shown to be dependent upon the community composition,_and the fish prey species utilized may vary considerably between sites and over time (Sánchez-Hernández \& Amundsen, 2015.) Thus piscivorous trout are likely heterogeneous in origin and different forms of piscivory are probably not homologous. At least in some, but not all locations (demonstrated by $S$. trutta in Loch Awe), it is very likely that the piscivorous life history strategy may be adopted by those individuals that during early ontogeny (prior to switching to fish feeding) grow fastest, thus contradicting hypothesis one. Extraordinarily, there is a consistent pattern across lakes suggesting piscivory confers an extended longevity on individuals adopting a piscivorous life history strategy. The mechanisms through which this may manifest are poorly understood but worthy of future attention, although delayed maturation is likely to be a contributing factor.

In at least one of the lakes sampled, Loch Rannoch, piscivorous trout growth conformed to the conventional model of slow growth followed by fast growth after a switch to piscivory, however this was not evident in the other two lakes sampled. The conclusion of this study is that there are multiple ontogenetic routes to piscivory in S. trutta and most likely in other species also. These data demonstrate individuals exhibiting similar phenotypes as adults, may have arisen though different juvenile strategies. 


\section{ACKNOWLEDGEMENTS}

303

304

305

306

307

308

309

310

311

312

313

314

315

316

317

318

319

320

321

322

323

324

325

We appreciate the time spent by two anonymous referees on revising this manuscript and thank them for their extensive and useful comments which strengthened this manuscript substantially. We thank Dr. James Barry for his extremely useful comments in preparation of this manuscript. We would also like to thank the Ferox85 Group for sponsoring some of the work, the Argyll Fisheries Trust and Dave Greenwood. This work was supported by funding from the European Union's INTERREG IVA Programme (Project 2859 'IBIS') managed by the Special EU Programmes Body.

\section{REFERENCES}

Allan, I. R. H., \& Ritter, J. A. (1977). Salmonid terminology. Journal du Conseil 37, 293299.

Appelberg, M., Berger, H.M., Hesthagen, T., Kleiven, E., Kurkilahti, M., Raitaniemi, J. \& Rask, M. (1995). Development and intercalibration of methods in Nordic freshwater fish monitoring. Water, Air, and Soil Pollution 85, 401-406.

Ball, J. N. (1961).On the food of the brown trout of Llyn Tegid. Proceedings of the Zoological Society of London 137, 599-622.

Berg, A., \& Grimaldi, E. (1967). A critical interpretation of the scale structures used for determination of annuli in fish growth studies. Memorie dell'Instituto Italiano di Idrobiologia 21, 225-239.

Campbell, R. N. (1971). The growth of brown trout Salmo trutta L. in northern Scottish lochs with special reference to the improvement of fisheries. Journal of Fish Biology 3, 128.

Campbell, R. N. (1979). Ferox trout, Salmo trutta L., and charr, Salvelinus alpinus (L.), in Scottish lochs. Journal of Fish Biology 14, 1-29. 
Duguid, R. A., Ferguson, A., \& Prodöhl, P. (2006). Reproductive isolation and genetic differentiation of ferox trout from sympatric brown trout in Loch Awe and Loch Laggan, Scotland. Journal of Fish Biology 69, 89-114.

Elliott, J. M., \& Hurley, M. A. (2000). Daily energy intake and growth of piscivorous brown trout, Salmo trutta. Freshwater Biology 44, 237-245.

Ferguson, A., \& Mason, F. M. (1981). Allozyme evidence for reproductively isolated sympatric populations of brown trout Salmo trutta L. in Lough Melvin, Ireland. Journal of Fish Biology 18, 629-642.

Ferguson, A., \& Taggart, J. B. (1991). Genetic differentiation among the sympatric brown trout (Salmo trutta) populations of Lough Melvin, Ireland. Biological Journal of the Linnean Society 43, 221-237.

Ford, J.K., Ellis, G.M., Olesiuk, P.F. \& Balcomb, K.C. (2010). Linking killer whale survival and prey abundance: food limitation in the oceans' apex predator?. Biology Letters 6, $139-142$.

Fraser, D., Adams, C.E. \& Huntingford, F.A. (1998). Trophic polymorphism among Arctic charr Salvelinus alpinus L., from Loch Ericht, Scotland. Ecology of Freshwater Fish 7, 184-191.

Freyhof, J., \& Kottelat, M. (2008). Salmo ferox. The IUCN Red List of Threatened Species, 2008, e.T135577A4150683.

Greer, R. (1995). Ferox trout and arctic charr: a predator, its pursuit and its prey. London. Swan-Hill Press.

Grey, J. (2001). Ontogeny and dietary specialization in brown trout (Salmo trutta L.) from Loch Ness, Scotland, examined using stable isotopes of carbon and nitrogen. Ecology of Freshwater Fish 10, 168-176. 
350 Hamilton, K.E., Ferguson, A., Taggart, J.B., Tomasson, T., Walker, A. \& Fahy, E. (1989). Post-glacial colonization of brown trout, Salmo trutta L.: Ldh-5 as a phylogeographic marker locus. Journal of Fish Biology 35, 651-664.

Hughes, M. R., Dodd, J. A., Maitland, P. S., \& Adams, C. E. (2016a). Lake bathymetry and species occurrence predict the distribution of a lacustrine apex predator. Journal of Fish Biology 88, 1648 - 1654. DOI: 10.1111/jfb.12919

Hughes, M.R., Van Leeuwen, T.E., Cunningham, P.D. \& Adams, C.E. (2016b). Parentally acquired differences in resource acquisition ability between brown trout from alternative life history parentage. Ecology of Freshwater Fish early view

Jensen, H., Kahilainen, K.K., Amundsen, P.A., Gjelland, K.Ø., Tuomaala, A., Malinen, T. \& Bøhn, T. (2008). Predation by brown trout (Salmo trutta) along a diversifying prey community gradient. Canadian Journal of Fisheries and Aquatic Sciences, 65,18311841.

Jensen, H., Kiljunen, M., \& Amundsen, P. A. (2012). Dietary ontogeny and niche shift to piscivory in lacustrine brown trout Salmo trutta revealed by stomach content and stable isotope analyses. Journal of fish biology 80, 2448-2462.

Jonsson, N., Næsje, T. F., Jonsson, B., Saksgård, R., \& Sandlund, O. T. (1999). The influence of piscivory on life history traits of brown trout. Journal of Fish Biology 55, 11291141.

Juanes, F. (1994). What determines prey size selectivity in piscivorous fishes? In Theory and application in fish feeding ecology. Edited by D.J. Stouder, K.L. Fresh, and R.J. Feller. South Carolina University Press, Columbia: 79-100.

Kahilainen, K., \& Lehtonen, H. (2003). Piscivory and prey selection of four predator species in a whitefish dominated subarctic lake. Journal of Fish Biology 63, 659-672. 
Klemetsen, A., Amundsen, P. A., Dempson, J. B., Jonsson, B., Jonsson, N., O'Connell, M. F., \& Mortensen, E. (2003). Atlantic salmon Salmo salar L., brown trout Salmo trutta L. and Arctic charr Salvelinus alpinus (L.): a review of aspects of their life histories. Ecology of Freshwater Fish 12, 1-59.

L'Abée-Lund, J. H., Aass, P., \& Saegrov, H. (2002). Long-term variation in piscivory in a brown trout population: Effect of changes in available prey organisms. Ecology of Freshwater Fish 11, 260-269.

L'Abée-Lund, J. H., Langeland, A., \& Sægrov, H. (1992). Piscivory by brown trout Salmo trutta L. and Arctic charr Salvelinus alpinus (L.) in Norwegian lakes. Journal of Fish Biology 41, 91-101.

Mangel, M. (1996). Life history invariants, age at maturity and the ferox trout. Evolutionary Ecology 10, 249-263.

Mangel, M., \& Abrahams, M. V. (2001). Age and longevity in fish, with consideration of the ferox trout. Experimental Gerontology 36, 65-790.

Maitland, P.S. \& Adams, C.E., (2018). Arctic charr in the Lochs of Scotland. FastPrint:Peterborough

McKeown, N.J., Hynes, R.A., Duguid, R.A., Ferguson, A. \& Prodöhl, P.A. (2010). Phylogeographic structure of brown trout Salmo trutta in Britain and Ireland: glacial refugia, postglacial colonization and origins of sympatric populations. Journal of Fish Biology 76, 319-347.

McMeel, O.M., Hoey, E.M. \& Ferguson, A. (2001). Partial nucleotide sequences, and routine typing by polymerase chain reaction-restriction fragment length polymorphism, of the brown trout (Salmo trutta) lactate dehydrogenase, LDH-C1* 90 and* 100 alleles. Molecular Ecology 10, 29-34. 
398 Mittelbach, G.G. \& Persson, L. (1998). The ontogeny of piscivory and its ecological consequences. Canadian Journal of Fisheries and Aquatic Sciences 55, 1454-1465.

400 Prodöhl, P.A., Taggart, J.B. \& Ferguson, A. (1992). Genetic variability within and among sympatric brown trout (Salmo trutta) populations: multi-locus DNA fingerprint analysis. Hereditas $117,45-50$.

R Core Team. (2016). R: A language and environment for statistical computing. R

Foundation for Statistical Computing, Vienna, Austria. URL https://www.R-project.org/.

Sánchez-Hernández, J., \& Amundsen, P. A. (2015). Trophic ecology of brown trout (Salmo trutta L.) in subarctic lakes. Ecology of Freshwater Fish 24, 148-161.

407

Shearer, W. M. (1992). The Atlantic salmon: natural history, exploitation and future

408 management. Cambridge. Fishing News Books.

Sikkink, K. L., \& Snell-Rood, E. C. (2016). Plasticity paves the way in an adaptive radiation. Molecular ecology 25 6009-6011.

Steingrímsson, S. Ó., \& Gíslason, G. M. (2002). Body size, diet and growth of landlocked brown trout, Salmo trutta, in the subarctic River Laxá, North-East Iceland. Environmental Biology of Fishes 63, 417-426.

414 Taggart, J., Ferguson, A. \& Mason, F.M. (1981). Genetic variation in Irish populations of brown trout (Salmo trutta L.): electrophoretic analysis of allozymes. Comparative Biochemistry and Physiology Part B: Comparative Biochemistry 69, 393-412.

Thorne, A., MacDonald, A.I. \& Thorley, J.L. (2016). The abundance of large, piscivorous 418 Ferox Trout (Salmo trutta) in Loch Rannoch, Scotland. PeerJ 4, p.e2646.

Wollebaek, J., Heggenes, J., \& Roed, K. H. (2018). Life histories and ecotype conservation in an adaptive vertebrate: Genetic constitution of piscivorous brown trout covaries with habitat stability. Ecology and evolution 8, 2729-2745. 
419 TABLE I. Von Bertalanffy growth parameters for the first 6 years of growth of each life history 420 type in each study lake, based on the results of back-calculated size/data.

\begin{tabular}{llllll}
\hline Location & Life History & K & Linf & t0 & $n$ \\
\hline Loch Awe & Invertebrate feeding trout & 0.10 & 47 & -0.06 & 39 \\
& Ferox trout & 0.13 & 100 & 0.13 & 33 \\
Loch Rannoch & Invertebrate feeding trout & 0.27 & 34 & 0.31 & 40 \\
& Ferox trout & 0.13 & 62 & 0.25 & 71 \\
Loch na Sealga & Invertebrate feeding trout & 0.30 & 34 & 0.22 & 23 \\
& Ferox trout & 0.31 & 33 & 0.38 & 14 \\
\hline
\end{tabular}

421 TABLE II. Likelihood ratios tests of growth parameters for the first 6 years of growth between 422 sympatric ferox and invertebrate feeding trout based on the results of back-calculated size/data. 423 Significant differences $(\mathrm{P}<0.05)$ are highlighted in bold. 


\begin{tabular}{llllc}
\hline Location & Parameter & Chi sq & df & $P$ \\
\hline Loch Awe & Linf & 14.49 & 1 & $\mathbf{0 . 0 0 1}$ \\
& K & 11.69 & 1 & $\mathbf{0 . 0 0 1}$ \\
Loch Rannoch & Linf & 3.76 & 1 & $\mathbf{0 . 0 5 2}$ \\
& K & 31.48 & 1 & $\mathbf{0 . 0 0 1}$ \\
Loch na Sealga & to & 24.37 & 1 & $\mathbf{0 . 0 0 1}$ \\
& Linf & 1.66 & 1 & 0.198 \\
& K & 1.16 & 1 & 0.281 \\
& to & 0.41 & 1 & 0.522 \\
& & 5.97 & 1 & $\mathbf{0 . 0 1 5}$ \\
\hline
\end{tabular}

424 TABLE III. Comparison of length-at-age, using Welch's t-tests, in the first three years of 425 growth and the last 3 years of growth between ferox trout and invertebrate feeding trout from 426 the same lake system, based on the results of back-calculated size/data. Significant differences 427 are highlighted in bold. 


\begin{tabular}{lllll} 
Lake & Age & $t$ & $d f$ & $P$ \\
\hline Awe & $1-3$ years & -6.32 & 146.08 & $<\mathbf{0 . 0 0 1}$ \\
& $4-6$ years & -14.78 & 130.77 & $<\mathbf{0 . 0 0 1}$ \\
\multirow{2}{*}{ Rannoch } & $1-3$ years & 0.88 & 236.09 & 0.38 \\
& $4-6$ years & -3.05 & 252.37 & $<\mathbf{0 . 0 1}$ \\
na Sealga & $1-3$ years & -0.32 & 81.55 & 0.75 \\
& $4-6$ years & -0.87 & 36.89 & 0.39
\end{tabular}

428 Figure 1. Von Bertalanffy growth curves, on the first 6 years of growth, for ferox trout $(\bullet)$ 429 and invertebrate feeding trout (O) from each study lake; (A) Loch Awe, (B) Loch Rannoch, 430 (C) Loch na Sealga and the age structure of ferox trout ( $\square$ ) and invertebrate feeding trout ( $\square$ ) 431 from each study lake; (D) Loch Awe, (E) Loch Rannoch, (F) Loch na Sealga. 
433
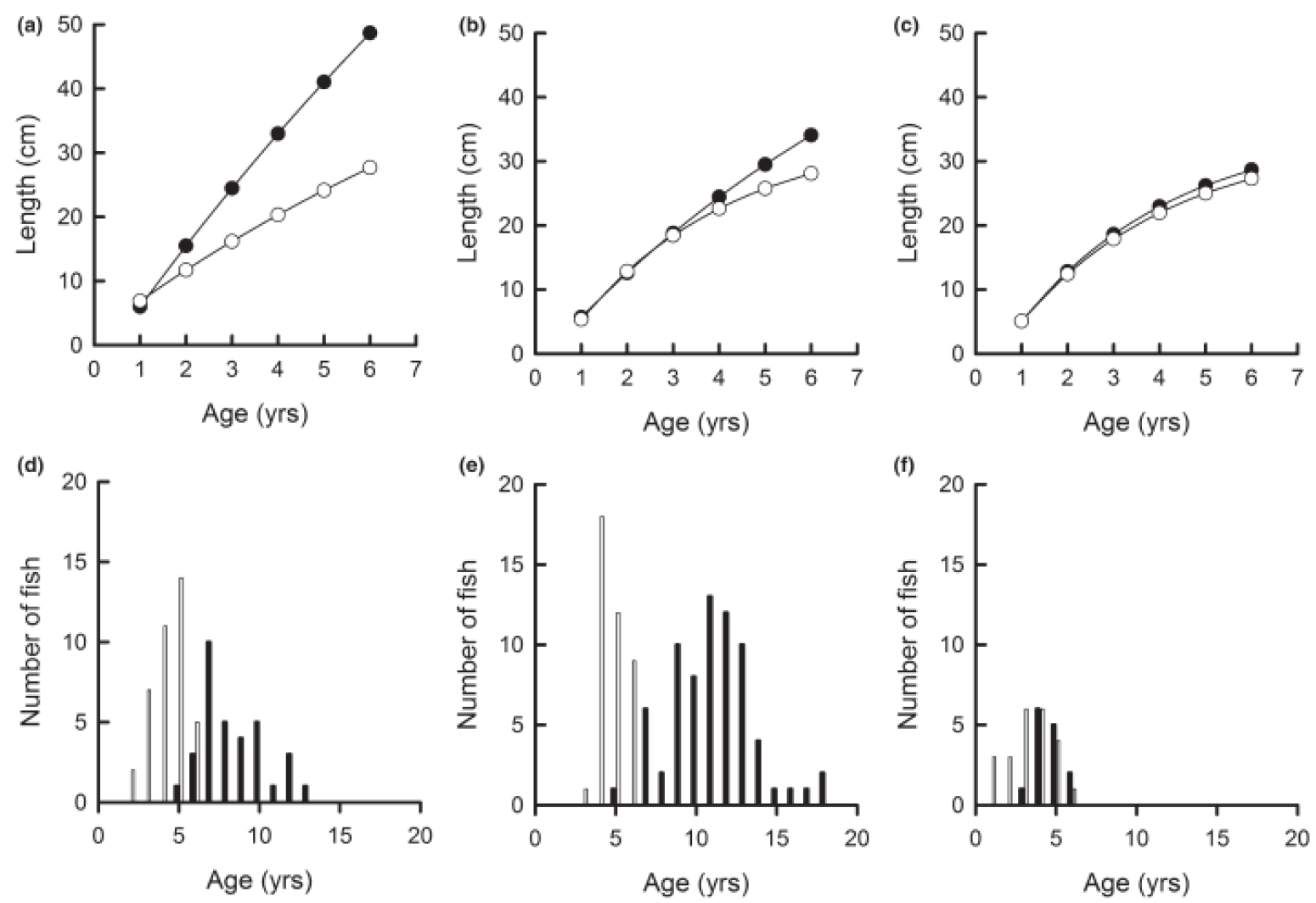

434

Figure 1. 